
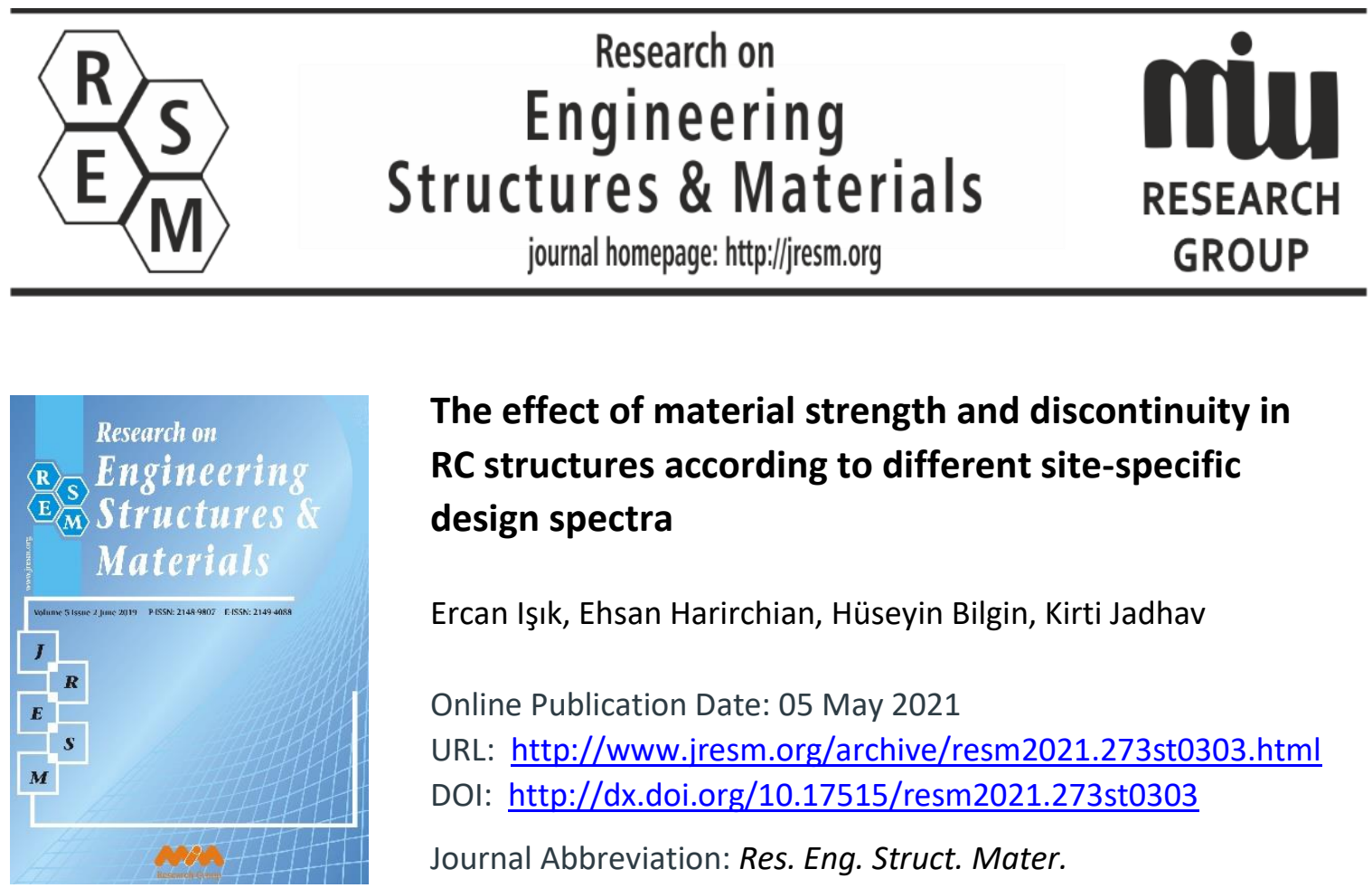

\title{
The effect of material strength and discontinuity in RC structures according to different site-specific design spectra
}

Ercan Işık, Ehsan Harirchian, Hüseyin Bilgin, Kirti Jadhav

Online Publication Date: 05 May 2021

URL: http://www.jresm.org/archive/resm2021.273st0303.html

DOI: http://dx.doi.org/10.17515/resm2021.273st0303

Journal Abbreviation: Res. Eng. Struct. Mater.

\section{To cite this article}

Işık E, Harirchain E, Bilgin $\mathrm{H}$, Jadhav $\mathrm{K}$. The effect of material strength and discontinuity in RC structures according to different site-specific design spectra. Res. Eng. Struct. Mater., 2021; $7(3)$ 413-430.

\section{Disclaimer}

All the opinions and statements expressed in the papers are on the responsibility of author(s) and are not to be regarded as those of the journal of Research on Engineering Structures and Materials (RESM) organization or related parties. The publishers make no warranty, explicit or implied, or make any representation with respect to the contents of any article will be complete or accurate or up to date. The accuracy of any instructions, equations, or other information should be independently verified. The publisher and related parties shall not be liable for any loss, actions, claims, proceedings, demand or costs or damages whatsoever or howsoever caused arising directly or indirectly in connection with use of the information given in the journal or related means.

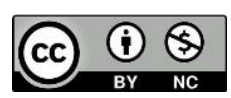

Published articles are freely available to users under the terms of Creative Commons Attribution - NonCommercial 4.0 International Public License, as currently displayed at here (the "CC BY - NC"). 


\title{
Research on Engineering Structures \& Materials
}

journal homepage: http://jresm.org

Research Article

\section{The effect of material strength and discontinuity in RC structures according to different site-specific design spectra}

\author{
Ercan Işık ${ }^{1, a}$, Ehsan Harirchian 2,b, Hüseyin Bilgin*3,c, Kirti Jadhav 4,d \\ ${ }^{1}$ Department of Civil Engineering, Bitlis Eren University, Bitlis, Turkey \\ ${ }^{2}$ Institute of Structural Mechanics (ISM), Bauhaus-Universität Weimar, Weimar, Germany \\ ${ }^{3}$ Department of Civil Engineering, Epoka University, Tirana, Albania \\ ${ }^{4}$ Faculty of Civil Engineering , Bauhaus-Universität Weimar, Weimar, Germany
}

\begin{abstract}
Article Info Abstract
Article history:

Received 03 Mar 2021

Revised 02 Apr 2021

Accepted 04 May 2021

Keywords:

Structural analysis; Design spectra; Material strength; Reinforced-concrete;

Seismic-induced damages in reinforced-concrete (RC) buildings were primarily associated with materials' low strength and poor properties. This study aims to investigate the seismic response of RC structures according to the different material's strength and design spectra. Adaptive static pushover and eigenvalue analysis were performed for four different design spectra, five types of concrete, and two reinforcement grades. Four different design spectra were obtained by considering discrete geographical locations with different earthquake risks via the updated Turkish Earthquake Hazard Map 2018. Structural analysis was carried out for a sample RC building using these spectrum curves and material strengths. It has been observed that the structure becomes more rigid as the strength of concrete increases. This situation manifested itself with an increase in period values and a decrease in the stiffness values. Stiffness values of the building are independent of reinforcement. As the concrete strength decreases, the structure's seismic capacity decreases while the displacement's demand for predicted performance levels increases. Moreover, an increase in the tensile strength of reinforcements substantially increases the seismic capacity of the building. The study also determines that the site-specific design spectra obtained for different provinces are used in the analysis affects the demand displacements values considerably. The material differentiation between the stories in the building was also examined in this study. It can be a source in terms of how material discontinuity affects building performance.
\end{abstract}

\section{Introduction}

In recent years, destructive earthquakes have caused large-scale losses for lives and properties, bringing forward the importance of seismic studies, research, and scientific developments. Several parameters such as number of stories, soft/weak story, short column, irregularity in plan, local soil conditions and hill-slope effect will adversely affect the behaviour of structures following earthquake loads. These parameters were also investigated and considered for rapid evaluation of structures. Parameters that will decrease the structural resistance mechanism will increase the amount of damage that might occur [1,2]. Numerous methods are developed to evaluate the building's seismic safety and performance, such as rapid visual screening [3-8] and application of modern computational techniques including machine learning [9-11], but design spectra are one of the most essential parameters to be used in determining the seismic safety factor of buildings. Design spectra can be obtained by combining the local soil conditions and seismicity elements of that particular region. Local ground conditions significantly affect

\footnotetext{
${ }^{*}$ Corresponding author: hbilgin@epoka.edu.al

a orcid.org/0000-0001-8057-065X; b orcid.org/0000-0003-0113-2120; c orcid.org/0000-0002-5261-3939;

d orcid.org/0000-0002-0048-3693
} 
the design spectra. Moreover, changes in spectra also affect the target displacements of structures [12-16]. Building design and evaluation become more meaningful by using sitespecific earthquake spectra.

Reinforced-concrete (RC) structures are widely used in developed countries and have an important role in terms of seismic-induced damage [17-19]. In such structures, the structural elements are made by joining reinforcement and concrete. Earthquake resistance of such structures decreases due to weaknesses in resistance mechanisms. Their vulnerability increases even in low-intensity earthquakes, depending on the amount of these weaknesses. In RC structures, it is associated with low strength and weak properties of concrete as the first cause of damage. Also, it should not be overlooked that the reinforcement used is straight or ribbed.

Seismic zones were expressed in four different ways, according to the Turkish Seismic Design Code-2007 (TSDC-2007) [20]. These seismic zones were removed with the updated seismic design code in 2018 (TBEC-2018) [21]. Site-specific design spectra should be used for any geographic location. One of the aims of the study is to examine the effect of different design spectra. In terms of seismicity level, Bingöl is located on level 1, Ağrı on level 2, Artvin on level 3, and Konya level 4, respectively, which were selected as case studies. Sitespecific design spectra were obtained for these settlements according to the updated Turkish Earthquake Hazard Map-2018. Eigenvalue and static adaptive pushover analyses were carried out separately for the five-story RC building using these design spectra. In addition, C8, C12, C16, C20 and C25 selections as a concrete class, S220, and S420 selections were made as to the reinforcement class. Concrete and reinforcement classes are taken into consideration as variables, and all other structural characteristics are kept constant. Interpretations were made by comparing all the obtained results.

This study aims to reveal how the material strengths predicted primarily affect building performance as a cause of damage, especially in RC structures after the earthquake. While acknowledging these differences, settlements with different seismicity risk were taken into consideration. The relationship between site-specific design spectra and material strengths has been tried to be revealed. Earthquake parameters were obtained for selected provinces by using updates earthquake hazard maps for Turkey. Short period mapping coefficient, spectral acceleration coefficient, maximum ground acceleration (PGA), maximum ground velocity (PGV), local ground effect coefficients, design spectral acceleration coefficients, and horizontal elastic spectrum curve were calculated individually here for selected provinces. The related information about earthquake damages due to concrete strength is also provided. Detailed information about obtaining design spectra for selected settlements is given. The RC building model used as an example is detailed. Information about the analysis used is presented.

Additionally, uncertainties in material strength are one of the essential factors to be taken into account. Concrete and reinforcement grades were selected when projecting RC buildings. In this case, it is impossible to attach the material grades selected at the project design stage on the building for various reasons. This means that the material strengths stipulated in the project cannot be achieved. Therefore, the calculations made during the projecting phase do not make any sense for the envisaged structure. This study also explains the failure of the stipulated material strengths at the project design stage. At the same time, the differentiation of material strength was also examined with the study. The discontinuities occur in material strength in RC structures due to different reasons for using different strength materials between stories. 


\section{Selection of Site-specific Earthquake Spectra}

There are many useful structural analysis parameters under earthquake risk [22-27]. Seismicity elements are one of these parameters. These elements are briefly defined as local soil conditions, fault groups, and their characteristics, historical earthquakes, and necessary periods. These parameters vary based on different geographic locations. Within the study's scope, four various settlements with different seismic risks were selected as Bingöl, Ağrı, Artvin, and Konya. Changes in analysis with varying risks of earthquakes were tried to be revealed within the scope of the study. The seismic zone expressions are no longer used in the updated Turkish Earthquake Hazard Map [28]. The usage of site-specific design spectra has emerged as the most significant change in updated Turkish Building Earthquake Code -2018. The site-specific seismic hazard evaluation is the main advantage of the new seismic code. It is necessary to mention that the latest update yields more reasonable assessments in structural performance. The representation of the selected provinces on this map was shown in Figure 1.

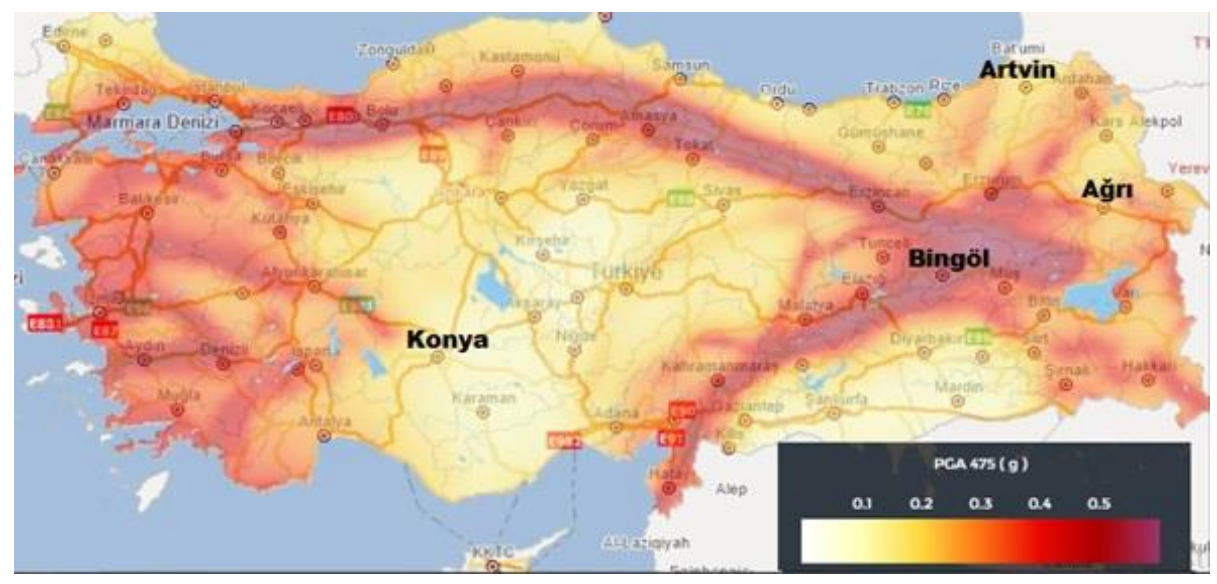

Fig. 1 Four different settlements that selected for this study

For all geographic locations, the standard design earthquake ground motion (DD-2) for an earthquake with a $10 \%$ annual probability of excess (recurrence period 475 years) and local soil conditions ZA class were selected for spectra curves and earthquake parameters. The properties of the ZA class were given in Table 1.

Table 1. Properties of ZA type according to TSDC-2018 [18]

\begin{tabular}{ccc}
\hline \multirow{2}{*}{ Local Ground Type } & \multirow{2}{*}{ Type of Ground } & Average at the top 30 meters \\
\cline { 3 - 3 } & & $\left(\mathrm{V}_{\mathrm{S}}\right)_{30}[\mathrm{~m} / \mathrm{s}]$ \\
\hline ZA & Strong, hard rocks & $>1500$ \\
\hline
\end{tabular}

In this study, the map spectral acceleration coefficient (SS), map spectral acceleration coefficient for the period of 1.0 second (S1), the most significant peak ground acceleration (PGA), the peak ground velocity (PGV), local ground impact coefficients (FS and F1), design spectral acceleration coefficients (short-period design spectral acceleration coefficient (SDS), and design spectral acceleration coefficient (SD1) for 1.0 second period) and horizontal elastic spectrum values were calculated separately via the Turkey Earthquake Hazard Maps Interactive Web Application [28]. SS for 0.2s and S1 spectral acceleration values in $1.0 \mathrm{~s}$ are calculated directly from the application for a $5 \%$ damping ratio. Local 
ground effect coefficient FS is derived from Table 2 in the short period zone and F1 was calculated according to Table 3 in the 1.0s period for local ground type ZA.

Table 2. Local soil effect coefficients ( $F_{S}$ ) for ZA soil type according to TBEC-2018 [21]

\begin{tabular}{ccccccc}
\hline Local Soil & \multicolumn{6}{c}{ Local ground effect coefficient $F_{\mathrm{s}}$ for the short period zone } \\
Type & $\mathrm{Ss}_{\mathrm{s}} \leq 0.25$ & $\mathrm{Ss}_{\mathrm{s}}=0.50$ & $\mathrm{Ss}_{\mathrm{s}}=0.75$ & $\mathrm{Ss}_{\mathrm{s}}=1.00$ & $\mathrm{Ss}_{\mathrm{s}}=1.25$ & $\mathrm{Ss}_{\mathrm{s}} \geq 1.50$ \\
\hline ZA & 0.8 & 0.8 & 0.8 & 0.8 & 0.8 & 0.8 \\
\hline
\end{tabular}

Table 3. Local soil effect coefficients $\left(\mathrm{F}_{1}\right)$ for ZA soil type according to TBEC-2018 [21]

\begin{tabular}{ccccccc}
\hline Local Soil & \multicolumn{6}{c}{ Local ground effect coefficient $\mathrm{F}_{1}$ for 1.0 second period } \\
Type & $\mathrm{S}_{1} \leq 0.10$ & $\mathrm{~S}_{1}=0.20$ & $\mathrm{~S}_{1}=0.30$ & $\mathrm{~S}_{1}=0.40$ & $\mathrm{~S}_{1}=0.50$ & $\mathrm{~S}_{\mathrm{s}} \geq 0.60$ \\
\hline ZA & 0.8 & 0.8 & 0.8 & 0.8 & 0.8 & 0.8 \\
\hline
\end{tabular}

Referring to the Table 2 and Table 3, FS and F1 coefficients for ZA take a constant value of 0.8 . This situation is also valid for ZB soil type and it differs for other soil types that given in TBEC-2018 (ZC, ZD; ZE). This is due to the fact that ZA and ZB soil types are solid ground. Short period design spectral acceleration coefficient (SDS) and design spectral acceleration coefficient (SD1) values for 1.0 seconds are calculated as follows;

$$
\begin{aligned}
& S_{D S}=S_{S} . F_{S} \\
& S_{D 1}=S_{1} \cdot F_{1}
\end{aligned}
$$

The comparison of the earthquake parameters obtained for selected provinces in this study are presented in Table 4.

Table 4. Comparison of earthquake parameters for selected provinces

\begin{tabular}{ccccc}
\hline \multirow{2}{*}{ Parameter } & \multicolumn{4}{c}{ Province } \\
\cline { 2 - 5 } & Bingöl & Ağrı & Artvin & Konya \\
\hline Ss & 1.596 & 0.547 & 0.425 & 0.307 \\
S $_{1}$ & 0.419 & 0.152 & 0.116 & 0.073 \\
PGA (g) & 0.648 & 0.234 & 0.185 & 0.133 \\
PGV(cm/s) & 41.836 & 13.588 & 10.467 & 6.688 \\
FS & 0.800 & 0.800 & 0.800 & 0.800 \\
F $_{1}$ & 0.800 & 0.800 & 0.800 & 0.800 \\
S $_{\text {DS }}$ & 1.277 & 0.438 & 0.341 & 0.246 \\
S $_{\text {D1 }}$ & 0.335 & 0.122 & 0.093 & 0.058 \\
\hline
\end{tabular}

A comparison of horizontal elastic design spectra obtained for selected cities was shown in Figure 2. Here, the horizontal axis represents the period value (T), and the vertical axis represents the horizontal elastic design spectral acceleration (Sae). 


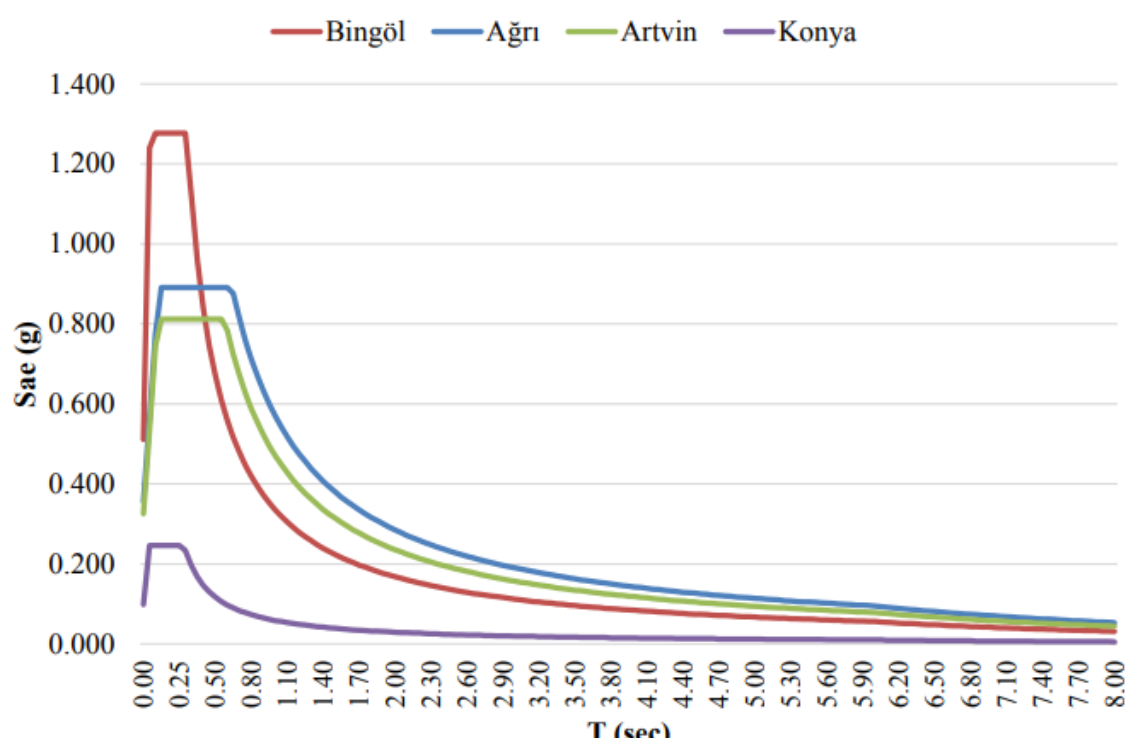

T (sec)

Fig. 2 Comparison of horizontal elastic design spectra

\section{Failures According to Low Strength of RC}

The strength of materials directly affects structures under various loads. Materials that are insufficient alone can become sufficient in terms of strength by combining additional materials. $\mathrm{RC}$ is a widely used composite building material that obtained by combining two different materials such as concrete and steel. The most important property expected from concrete is compressive strength and the tensile strength expected from steel. The classification of these two materials is made by considering these properties. Earthquake damages are primarily associated with concrete with poorer properties than these two materials in any RC structure. Therefore, the quality of these two materials largely determines the quality of any RC structural system. Concrete is a composite material, including various materials such as cement, aggregate, water and other additional materials. Furthermore, concrete production steps are very much, such as calculation of composition, transportation, concreting, compaction, and curing of concrete. The fact that it is obtained by combining many materials and the production stages are very different affects the concrete strength negatively. A concrete with low strength that seems sufficient under vertical loads cannot withstand horizontal loads during an earthquake. The concrete shows a more ductile behaviour as a result of the different reinforcements placed in the concrete in the RC structural system. However, if the compressive strength of concrete is low, it causes adherence between concrete and reinforcement to be sufficient even at low stresses. In this case, longitudinal reinforcements are easily stripped from the concrete, longitudinal reinforcements bonded with tight stirrups sprains. The materials contained in concrete, environmental conditions, application errors, bad workmanship, degree of compression, insufficient protection/maintenance and cement type generally cause low strength of concrete. However, inappropriate grain distribution and size in aggregate, direct use of aggregate obtained from rivers found in the region, and inadequate concrete compression processes led to concrete with a little resistance to segregation. The usage of smooth reinforcement in RC reduces the capacity in terms of both strength and adherence. This situation has been revealed again in the 2020 Sivrice (Elazığ) earthquake lastly in Turkey as presented in the Figure 3. 

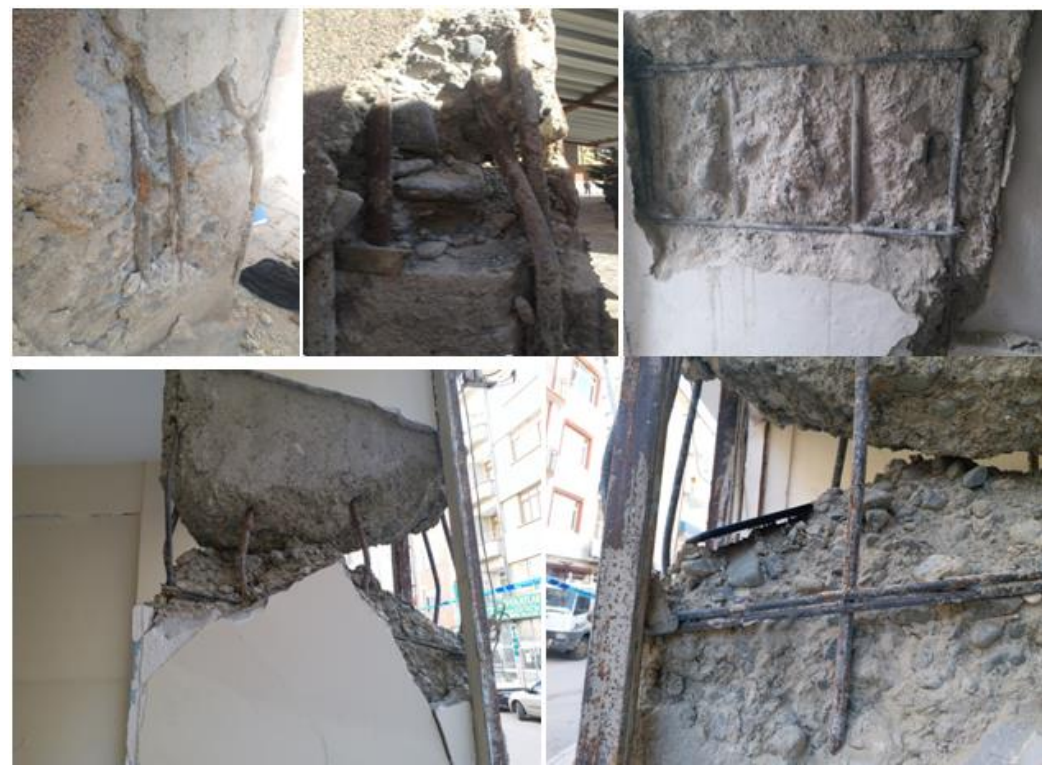

Fig. 3 Damages in RC according to poor/low strength after 2020 Sivrice earthquake

Due to the low concrete strength and the smooth reinforcement used, damage was observed in different earthquakes. Some of these damages were shown in Figure 4.

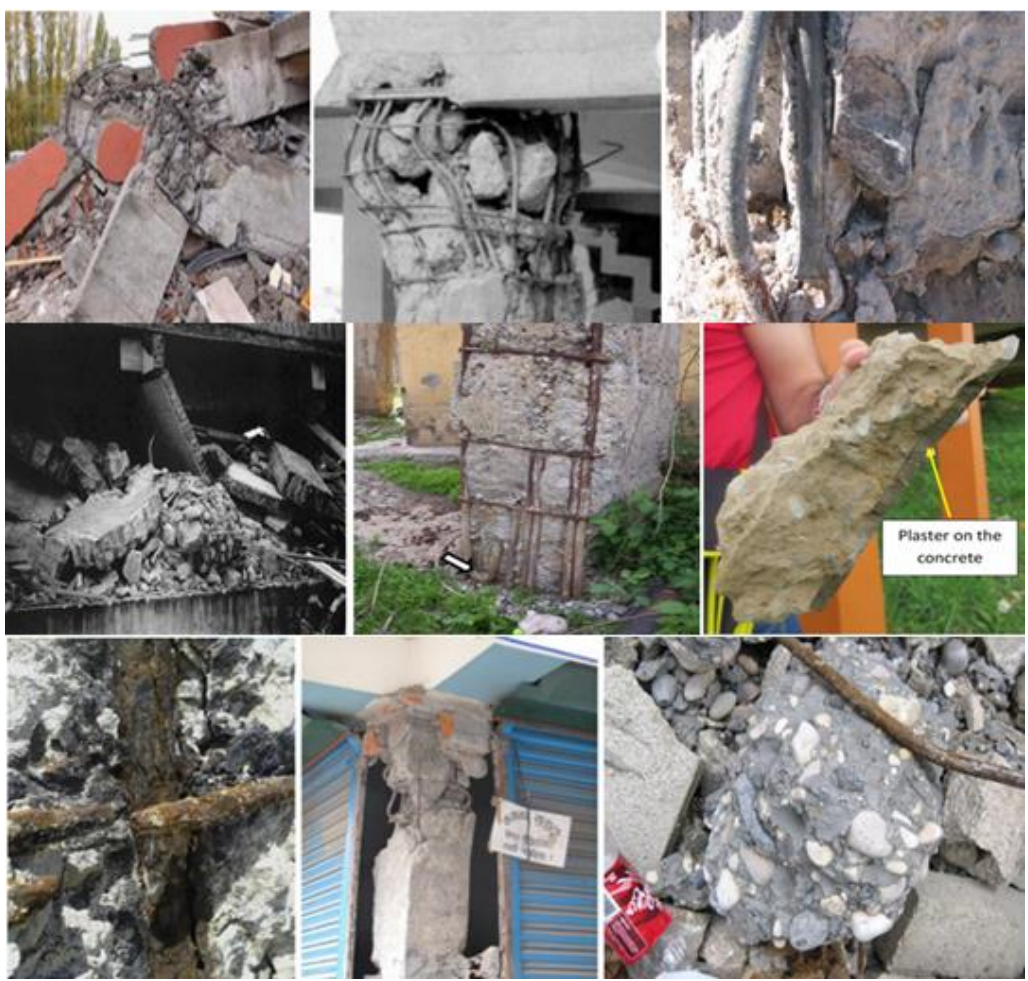

Fig. 4 Poor quality/ low strength material damages after different earthquakes [29-37] 


\section{Structural Analyses}

Structural analysis for the provinces was performed using the Seismostruct software (Seismosoft, 2018). The static adaptive pushover analysis, which is applied in predicting the horizontal capacity of a structure, taking full account of the effect that the deformation of the latter and the frequency content of input motion have on its dynamic response characteristics, was used. Here, analyses were performed by considering the mode shapes and participation factors obtained from the eigenvalue analyses in each step during the adaptive pushover analysis. This method allows the use of site-specific spectra. Load control types used in this study are similar to conventional pushover analysis [38-46]. Material models have an essential place in structural analysis [47]. The nonlinear concrete model [48] and steel model [49] were used for concrete and steel material, respectively. The stress-strain relationship of the material models considered for these models is demonstrated in Figure 5. Here, the vertical axis represents stress and horizontal axis represents the strain under the stress.
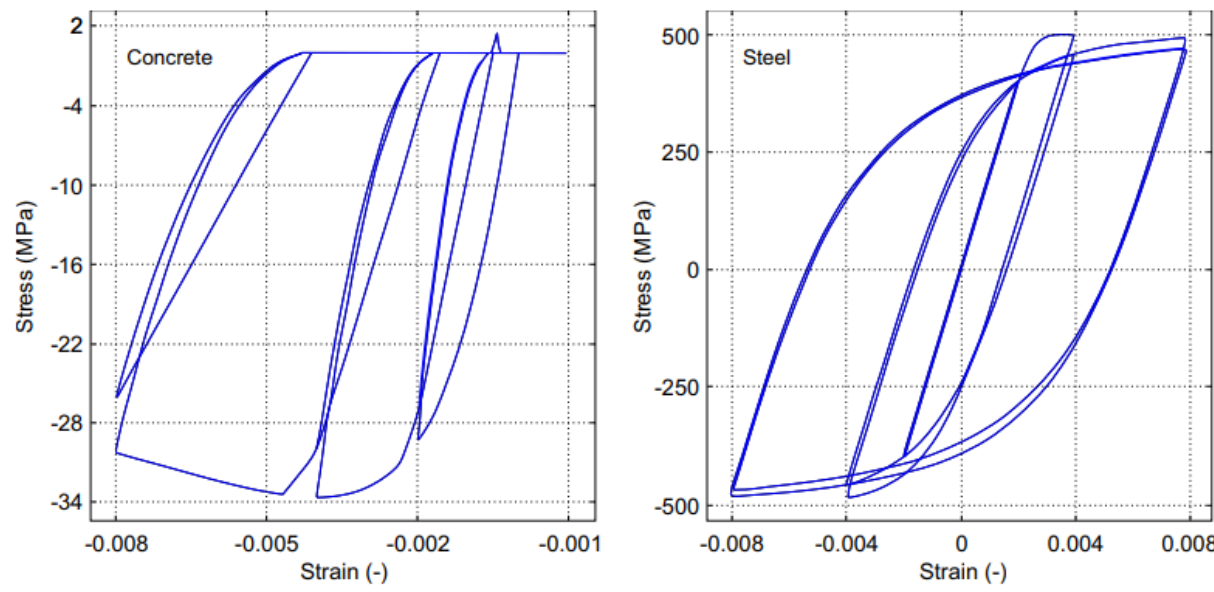

Fig. 5 Material models for concrete and steel considered in the study [50]

The characteristics of the five different concrete grades considered in this study are given in Table 5. The properties of the two different reinforcement grades considered in this study are given in Table 6.

Table 5. Properties of different concrete grades [51]

\begin{tabular}{cccccc}
\hline Parameter & C8 & C12 & C16 & C20 & C25 \\
\hline Mean compressive strength & 16000 & 20000 & 24000 & 28000 & 33000 \\
$(\mathrm{kPa})$ & 8000 & 12000 & 16000 & 20000 & 25000 \\
Nominal value $(\mathrm{kPa})$ & 1600 & 2000 & 2400 & 2800 & 3300 \\
Mean tensile strength $(\mathrm{kPa})$ & $1.88 \mathrm{E}+007$ & $2.10 \mathrm{E}+007$ & $2.30 \mathrm{E}+007$ & $2.48 \mathrm{E}+007$ & $2,69 \mathrm{E}+07$ \\
Modulus of elasticity $(\mathrm{kPa})$ & 0.002 & 0.002 & 0.002 & 0.002 & 0.002 \\
Strain at peak stress $(\mathrm{m} / \mathrm{m})$ & 24.00 & 24.00 & 24.00 & 24.00 & 24.00 \\
Specific weight $\left(\mathrm{kN} / \mathrm{m}^{3}\right)$ & & & & & \\
\hline
\end{tabular}


Table 6. Properties of different reinforcement grades [51]

\begin{tabular}{ccc}
\hline Parameter & S220 & S420 \\
\hline Mean compressive strength (kPa) & 253000 & 483000 \\
Modulus of elasticity (kPa) & $2.00 \mathrm{E}+08$ & $2.00 \mathrm{E}+08$ \\
Nominal value (kPa) & 220000 & 420000 \\
Yield strength (kPa) & 253000 & 483000 \\
Specific weight (kN/m3) & 78 & 78 \\
Strain hardening parameter (-) & 0.005 & 0.005 \\
Transition curve initial shape parameter & 20 & 20 \\
Transition curve shape calibrating coeff. A1 (-) & 18.50 & 18.50 \\
Transition curve shape calibrating coeff. A2 (-) & 0.15 & 0.15 \\
Isotropic hardening calibrating coeff. A3 (-) & 0 & 0 \\
Isotropic hardening calibrating coeff. A4 (-) & 1.00 & 1.00 \\
Fracture/buckling strain (-) & 0.10 & 0.10 \\
\hline
\end{tabular}

The blueprint of the selected RC structure is presented in Figure 6, and the 2D and 3D structural models and the applied loads are shown in Figure 7.

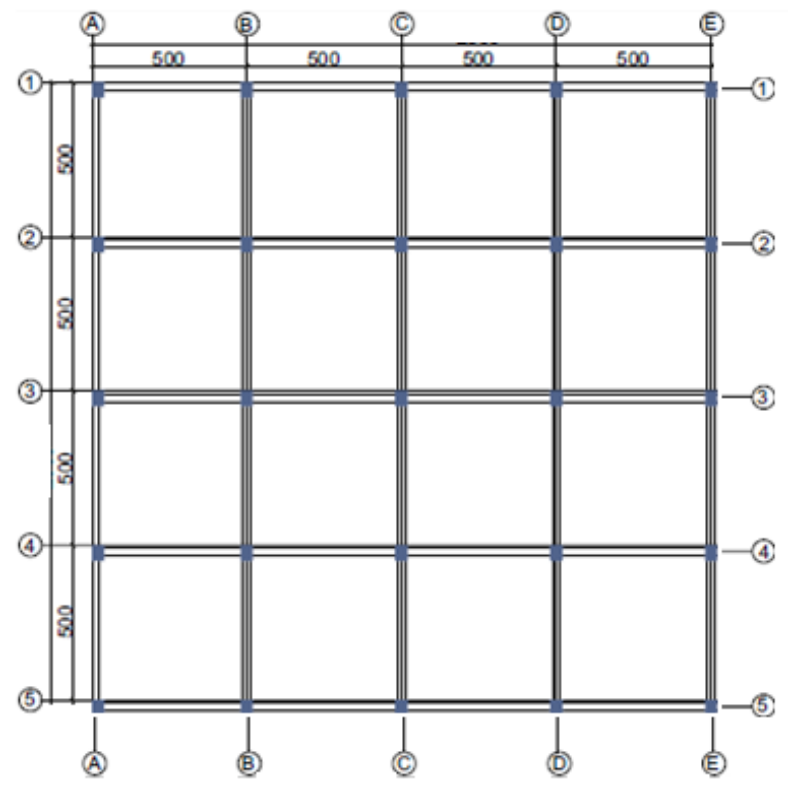

Fig. 6 The blueprint of sample model RC building 

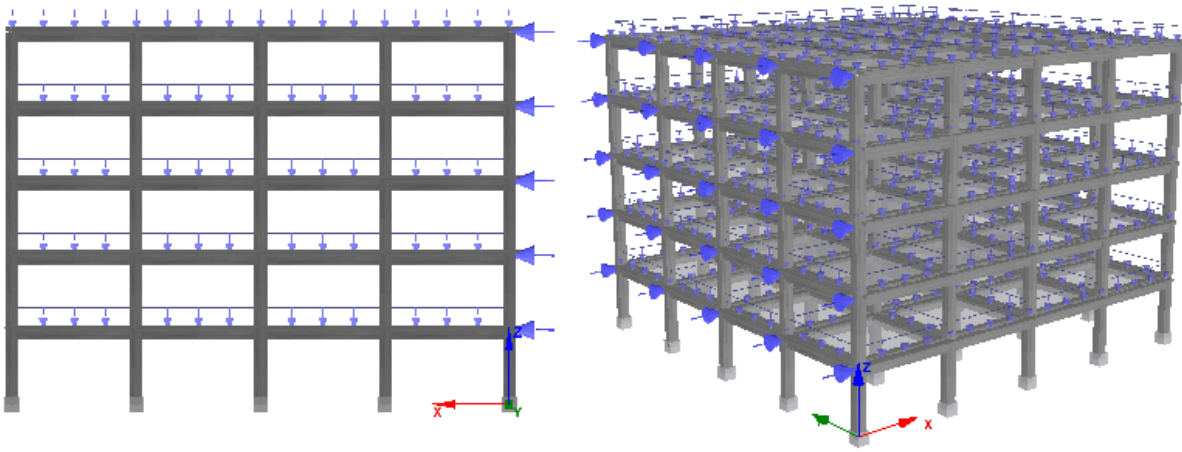

Fig. 7 2D and 3D models of the sample model RC building

Each story had an equal height and taken as $3 \mathrm{~m}$. All columns were selected as $0.40 \times 0.50 \mathrm{~m}$ and beams were selected as $0.25 \times 0.60 \mathrm{~m}$. The transverse reinforcements used in both elements were selected as $\phi 10 / 10$. The reinforcements used in the columns were selected as $4 \phi 20$ at corners and $4 \phi 16$ top bottom and left-right sides. The reinforcements used in the beams were selected as $4 \phi 16$ at lower side, $5 \phi 14$ upper side and $2 \phi 12$ at side. The columns and beams used in the structure are shown in Figure 8. The damping ratio was taken as \% 5 in all structural models. The ZA soil type was chosen as the local soil condition. The importance of structure was taken into consideration as Class II. The slabs were selected as rigid diaphragms.

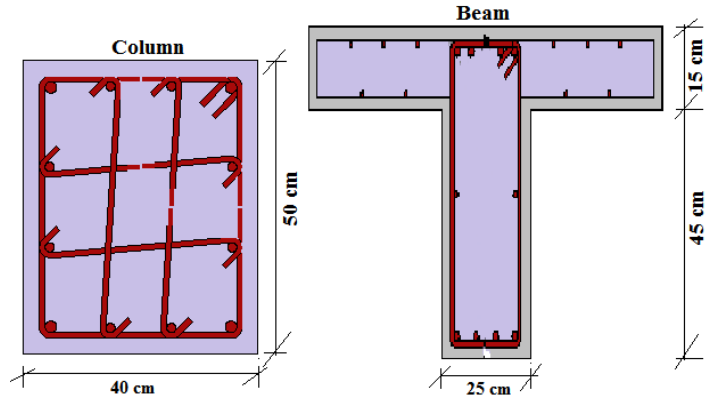

Fig. 8 Column and beam cross-sections

The dy value refers to displacement at the moment of yield and dint value refers to the intermediate displacement. Elastic stiffness (K_elas) and effective stiffness (K_eff) values were also calculated separately for selected provinces for different material strengths. Three different performance criteria were obtained for damage estimation. These are considered as near collapse (NC), significant damage (SD) and damage limitation (DL) according to Eurocode-8, (Part-3) [52].

\section{The Interaction Between Material Strength and Site-Specific Spectra}

The comparison of all values obtained in X direction for S220 and S420 has been presented in Tables 7 and 8, respectively. The comparison of the static pushover curves for S220 and S420 grades are presented in Figures 9. 

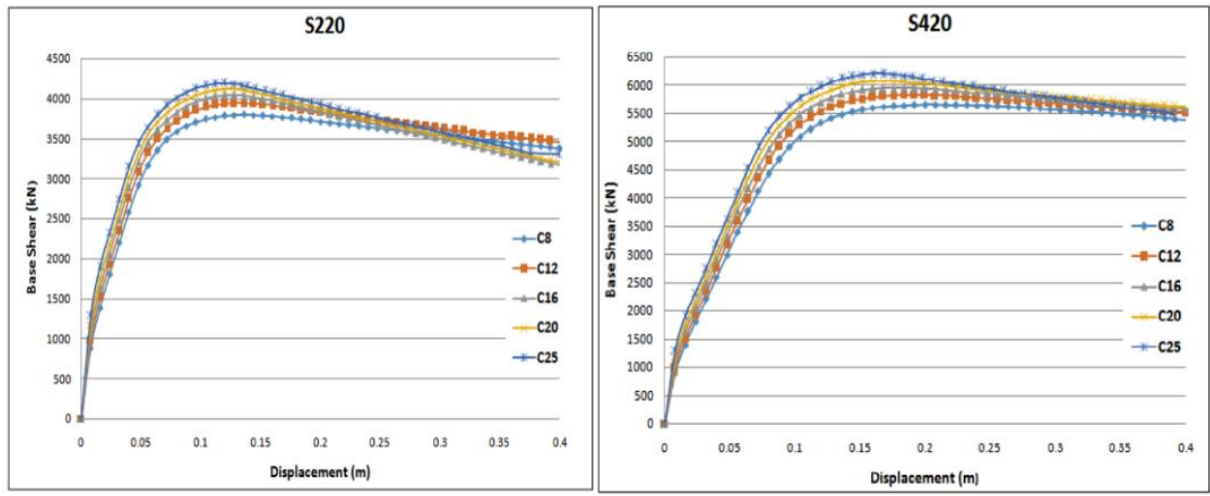

Fig. 9 Comparison of pushover curves for S220 and S420 for different concrete grades

Table 7. Comparison of values obtained in X direction for S220

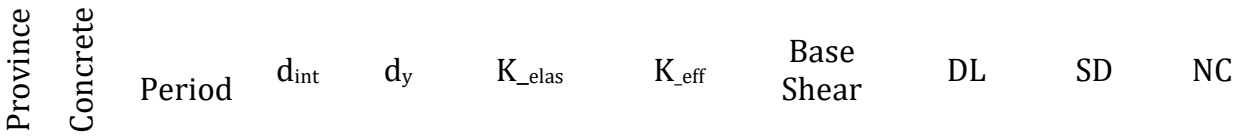

\begin{tabular}{|c|c|c|c|c|c|c|c|c|c|c|}
\hline \multirow{5}{*}{$\begin{array}{l}\overline{0}: 0 \\
: 0 \\
: 0\end{array}$} & C8 & 0.4429 & 0.061 & 0.136 & 109949.2 & 61788.6 & 3796.05 & 0.0948 & 0.1217 & 0.2109 \\
\hline & $\mathrm{C} 12$ & 0.4227 & 0.060 & 0.128 & 121202.8 & 65952.4 & 3943.33 & 0.0918 & 0.1178 & 0.2042 \\
\hline & C16 & 0.4066 & 0.058 & 0.128 & 132308.9 & 70333.2 & 4044.74 & 0.0889 & 0.1140 & 0.1977 \\
\hline & $\mathrm{C} 20$ & 0.3933 & 0.055 & 0.120 & 146060.4 & 74676.7 & 4118.61 & 0.0863 & 0.1107 & 0.1919 \\
\hline & C25 & 0.3795 & 0.052 & 0.120 & 160602.3 & 80067.8 & 4189.83 & 0.0833 & 0.1069 & 0.1853 \\
\hline \multirow{5}{*}{ 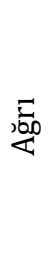 } & C8 & 0.4429 & 0.061 & 0.136 & 109947.7 & 61783 & 3796.18 & 0.0342 & 0.0439 & 0.0762 \\
\hline & C12 & 0.4227 & 0.060 & 0.128 & 121201.6 & 65950.5 & 3943.51 & 0.0331 & 0.0425 & 0.0737 \\
\hline & C16 & 0.4066 & 0.058 & 0.128 & 132307.9 & 70332.8 & 4044.75 & 0.0321 & 0.0412 & 0.0714 \\
\hline & $\mathrm{C} 20$ & 0.3933 & 0.055 & 0.12 & 146059.6 & 74677.2 & 4118.51 & 0.0312 & 0.0400 & 0.0693 \\
\hline & $\mathrm{C} 25$ & 0.3795 & 0.052 & 0.12 & 160601.4 & 80069.6 & 4189.79 & 0.0301 & 0.0386 & 0.0669 \\
\hline \multirow{4}{*}{ 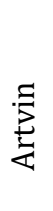 } & C8 & 0.4429 & 0.061 & 0.136 & 109948.2 & 61787.5 & 3796.04 & 0.0272 & 0.0349 & 0.0605 \\
\hline & $\mathrm{C} 12$ & 0.4227 & 0.060 & 0.128 & 121202 & 65954.2 & 3943.42 & 0.0263 & 0.0338 & 0.0586 \\
\hline & C16 & 0.4066 & 0.058 & 0.128 & 132308.1 & 70328.6 & 4044.85 & 0.0255 & 0.0327 & 0.0567 \\
\hline & $\mathrm{C} 20$ & 0.3933 & 0.055 & 0.12 & 146059.8 & 74677.5 & 4118.55 & 0.0248 & 0.0318 & 0.0551 \\
\hline \multirow{6}{*}{ 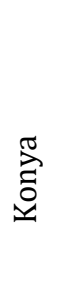 } & $\mathrm{C} 25$ & 0.3795 & 0.052 & 0.12 & 160601.6 & 80085.5 & 4190.07 & 0.0239 & 0.0307 & 0.0532 \\
\hline & C8 & 0.4429 & 0.061 & 0.136 & 109951.8 & 61791.1 & 3796.04 & 0.0195 & 0.0250 & 0.0433 \\
\hline & C12 & 0.4227 & 0.060 & 0.128 & 121205.6 & 65959.6 & 3943.48 & 0.0188 & 0.0242 & 0.0419 \\
\hline & C16 & 0.4066 & 0.058 & 0.128 & 132312.0 & 70320.8 & 4045.17 & 0.0182 & 0.0234 & 0.0406 \\
\hline & $\mathrm{C} 20$ & 0.3933 & 0.055 & 0.12 & 146065.4 & 74677.3 & 4118.56 & 0.0177 & 0.0227 & 0.0394 \\
\hline & $\mathrm{C} 25$ & 0.3795 & 0.052 & 0.12 & 160608.4 & 80080.7 & 4189.87 & 0.0171 & 0.0219 & 0.0380 \\
\hline
\end{tabular}


Table 8. Comparison of values obtained in X direction for S420

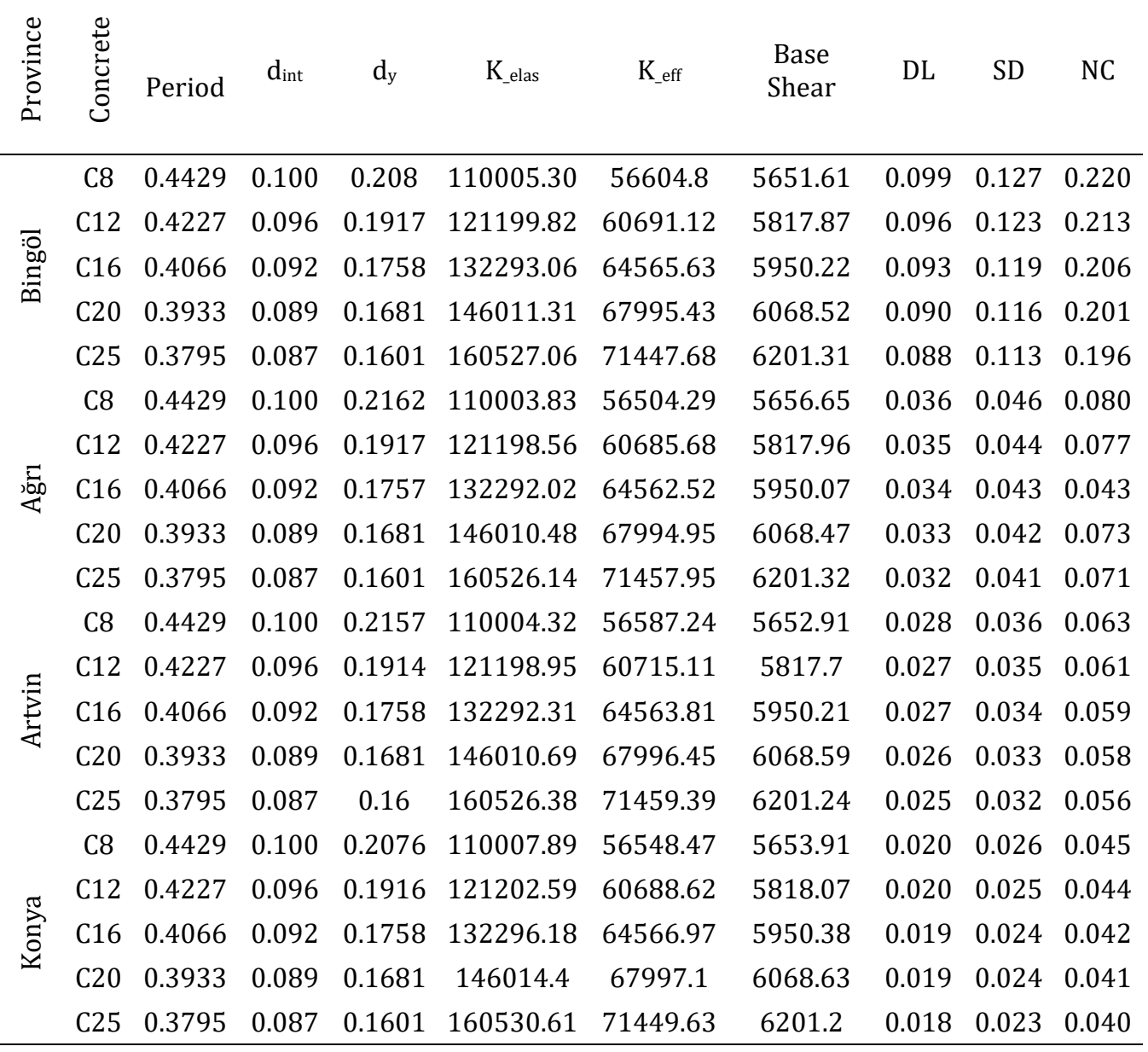

The comparison of PGA and target displacements for damage estimation was given in Table 9.

Table 9. Comparisons of earthquake - structural parameters

\begin{tabular}{cccccccc}
\hline Province & PGA & \multicolumn{3}{c}{ C25-S220 } & \multicolumn{3}{c}{ C25-S420 } \\
\hline Bingöl & 0.648 & 0.0833 & 0.1069 & 0.1853 & 0.088 & 0.113 & 0.196 \\
A ̆grı & 0.234 & 0.0301 & 0.0386 & 0.0669 & 0.032 & 0.041 & 0.071 \\
Artvin & 0.185 & 0.0239 & 0.0307 & 0.0532 & 0.025 & 0.032 & 0.056 \\
Konya & 0.133 & 0.0171 & 0.0219 & 0.038 & 0.018 & 0.023 & 0.040 \\
\hline
\end{tabular}




\section{The Effect of Material Discontinuity on Building Performance}

The differentiation of material strengths in the building has also been taken into account within this study's scope. The construction of the stories can be built at different times due to various RC structures that have no engineering services. Since concrete casting is carried out at different times, discontinuities occur in material strength within the building. As a result, concrete and reinforcement are used in different qualities in the first built parts and later built parts. This situation increases the difference of material strength between stories, especially with the widespread of ready mixed concrete. The difference in material strengths within the building increases as the construction date of the first parts of the buildings gets older. These differences to reveal the name of the specified minimum concrete and reinforcement grade in Turkey in the last three regulations were taken into account. Analyses were carried out using the RC building example in the previous section and the design spectrum obtained for Bingöl province. The lowest concrete and reinforcement grades were considered, which were specified in the last three seismic design codes in Turkey. The building models selected in this context are given in Table 10.

Table 10. Models selected for material discontinuity

\begin{tabular}{cc}
\hline Model & Description \\
\hline Model 1 & C14 - S220 (In whole structure) \\
Model 2 & C14 - S220 (only in 1st story)/ C20-S220 (All other stories) \\
Model 3 & C14 - S220 (only in 1st story)/ C20-S420 (All other stories) \\
Model 4 & C14 - S220 (only in 1st story)/ C25-S220 (All other stories) \\
Model 5 & C14-S220 (only in 1st story)/ C25-S420 (All other stories) \\
Model 6 & C14-S220 (only in 1st and 2nd stories) C20-S220 (All other stories) \\
Model 7 & C14-S220 (only in 1st and 2nd stories) C20-S420 (All other stories) \\
Model 8 & C14-S220 (only in 1st and 2nd stories) C25-S220 (All other stories) \\
Model 9 & C14-S220 (only in 1st and 2nd stories) C25-S420 (All other stories) \\
Model 10 & C20-S220 (In whole structure) \\
Model 11 & C25-S220 (In whole structure) \\
\hline
\end{tabular}

The analysis results obtained for the eleven different building models are shown in Table 11. 
Table 11. Results obtained from the change of the material grade within the building

\begin{tabular}{cccccccccc}
\hline Model & Period & \multirow{2}{*}{$\mathrm{d}_{\text {int }}$} & $\mathrm{d}_{\mathrm{y}}$ & K_elas & K_eff & $\begin{array}{c}\text { Base } \\
\text { Shear }\end{array}$ & DL & SD & NC \\
\hline Model 1 & 0.4142 & 0.0587 & 0.1280 & 126800.97 & 68139.18 & 4000.29 & 0.090 & 0.116 & 0.201 \\
Model 2 & 0.4011 & 0.0531 & 0.1120 & 143574.93 & 75468.82 & 4011.05 & 0.086 & 0.111 & 0.192 \\
Model 3 & 0.4011 & 0.5070 & 0.0880 & 143540.79 & 79580.68 & 4034.21 & 0.084 & 0.108 & 0.186 \\
Model 4 & 0.3927 & 0.0496 & 0.1042 & 154168.61 & 80902.27 & 4015.26 & 0.083 & 0.107 & 0.186 \\
Model 5 & 0.3927 & 0.0480 & 0.0880 & 154122.84 & 84990.65 & 4036.07 & 0.081 & 0.104 & 0.181 \\
Model 6 & 0.4076 & 0.0551 & 0.1202 & 138776.00 & 72623.01 & 4003.96 & 0.088 & 0.112 & 0.195 \\
Model 7 & 0.4076 & 0.0544 & 0.1200 & 138746.22 & 73661.28 & 4005.81 & 0.087 & 0.112 & 0.193 \\
Model 8 & 0.4034 & 0.0529 & 0.1199 & 143621.45 & 75860.41 & 4005.73 & 0.086 & 0.110 & 0.191 \\
Model 9 & 0.4034 & 0.0523 & 0.1120 & 143587.62 & 76593.32 & 4008.77 & 0.085 & 0.109 & 0.189 \\
Model 10 & 0.3933 & 0.0890 & 0.1681 & 146011.31 & 67995.43 & 6068.52 & 0.090 & 0.116 & 0.201 \\
Model 11 & 0.3795 & 0.087 & 0.1601 & 160527.06 & 71447.68 & 6201.31 & 0.088 & 0.113 & 0.196 \\
\hline
\end{tabular}

Table 12 gives examples of the load factors obtained for equal displacements when structural building systems contain different material strengths. The concrete grade was selected as a variable by keeping the reinforcement grade constant while making these comparisons.

Table 12. Comparison of load factors for equal relative displacement

\begin{tabular}{ccccccc}
\hline \multirow{2}{*}{ Model } & \multicolumn{5}{c}{ Relative Displacement (m) } & Load \\
\cline { 2 - 5 } & N511 & N411 & N311 & N211 & N211 & Factor \\
\hline Model 1 & & & & & & 15.82 \\
Model 10 & & & & & & 17.71 \\
Model 11 & & & & & & 19.16 \\
Model 2 & \multirow{2}{*}{0.016} & \multirow{2}{*}{0.015} & \multirow{2}{*}{0.012} & 0.008 & 0.0033 & 17.28 \\
Model 4 & & & & & & 18.31 \\
Model 6 & & & & & & 16.66 \\
Model 8 & & & & & & 17.16 \\
\hline
\end{tabular}

The comparison of relative displacement values in building models under equal load factors were shown in Table 13. Two different load factor values have been taken into account as an example.

Table 13. Comparison of relative displacement under equal load factors

\begin{tabular}{cccccccccccc}
\hline & \multicolumn{1}{c}{ Lelative Displacement (m) } \\
\cline { 2 - 11 } Model & \multicolumn{1}{c}{ Load Factor $=25$} \\
\cline { 2 - 11 } & N511 & N411 & N311 & N211 & N111 & N511 & N411 & N311 & N211 & N111 \\
\hline Model 1 & 0.034 & 0.031 & 0.0025 & 0.0167 & 0.071 & 0.127 & 0.121 & 0.109 & 0.088 & 0.046 \\
Model 10 & 0.030 & 0.028 & 0.023 & 0.0153 & 0.064 & 0.089 & 0.084 & 0.074 & 0.055 & 0.026 \\
Model 11 & 0.027 & 0.026 & 0.021 & 0.0141 & 0.059 & 0.079 & 0.075 & 0.065 & 0.048 & 0.023 \\
Model 2 & 0.031 & 0.029 & 0.024 & 0.0163 & 0.069 & 0.104 & 0.098 & 0.089 & 0.070 & 0.039 \\
Model 4 & 0.028 & 0.027 & 0.022 & 0.0154 & 0.068 & 0.096 & 0.091 & 0.082 & 0.065 & 0.037 \\
Model 6 & 0.032 & 0.030 & 0.024 & 0.0166 & 0.070 & 0.120 & 0.115 & 0.101 & 0.081 & 0.043 \\
Model 8 & 0.030 & 0.028 & 0.024 & 0.0166 & 0.070 & 0.111 & 0.106 & 0.097 & 0.079 & 0.041 \\
\hline
\end{tabular}




\section{Conclusions}

Eigenvalue and static adaptive pushover analysis for sample RC buildings were made for three different variables. All three selected parameters directly affect the earthquake behaviour of the structures. The first variable is the site-specific design spectrum according to the updated Turkish Earthquake Building Code-2018, which is one of the most important changes in this code. An analysis was carried out for four different cities which each located on different seismicity levels. Five different concrete classes have been selected as another variable. Meanwhile, two different reinforcement grades were considered as the last variable. As concrete strength increases, the deformability of it decreases.

As the strength of the concrete increases, the building's period value decreases, and the elastic and effective stiffness values increase. These show that the structure will be more rigid with the rise of the strength of the concrete. The decrease in concrete strength reduces the seismic capacity of the building. With the reduction of concrete strength, the target displacement values foreseen for the performance criteria expected from the building have increased. These results on concrete strength have remained valid for both reinforcement classes. The period value of the buildings did not change according to the reinforcement class. Elastic and effective stiffness values, which are calculated over crack and cracked sections, also remained constant. The seismic capacity of the buildings was significantly increased due to increasing the reinforcement strength. With the increase of reinforcement strength, the target displacement values have increased. The highest risk values among the provinces considered were calculated for the Bingöl province. The sitespecific design spectra did not change the period, elastic and effective stiffness, and seismic capacity values. However, the design spectra significantly altered the target displacement values for the performance criteria for damage estimation. The increase in PGA value also caused the target displacement to increase. The use of site-specific design spectra in the analysis and evaluation of structures allows a more realistic calculation of performance levels expected from the structure. It is clearly seen that a complete agreement was observed between the earthquake-structural analysis results by using the site-specific design spectra. The importance of material strength in RC structures with site-specific design spectra has been revealed once again in the light of the 2020 Sivrice earthquake. Since the seismicity elements of each geographic location are different, the results are expected to be varied. The construction of material strengths as projected in the project by obtaining engineering services will decrease the damage levels that may occur in the buildings to a lower level.

In columns and beams, both the normal and shear force capacities have increased with the increase in concrete strength. An effect of steel grade is not considered in seismic design code for limit values in normal force and shear force in columns and beams. The reinforcement ratios in the columns take constant values independently in the concrete and steel grade. However, this ratio of both concrete and reinforcement grade directly affects in the beams. As the concrete strength increased, the reinforcement ratios foreseen for the beams increased. As the reinforcement strength increased, the rate of reinforcement decreased. One of the most important causes of earthquake damages has revealed the effect of material strength on the building performance and limit conditions foreseen for forces with this study. In addition, analysis was carried out using the sitespecific design spectra foreseen in the updated Turkish seismic design code. The final results obtained once again demonstrated the importance of obtaining site-specific design spectra.

The material strengths can vary between stories in RC structures that do not receive engineering services and whose stories are built at different times. This causes 
discontinuity of the material in the building. In this context, analyses were performed by considering the minimum concrete grade, which was states in Turkey's last three seismic design codes. Low strength concrete is the leading cause of earthquake damage in RC structures in Turkey. In this respect, while the minimum concrete grade to be used in the 1975 code was C14, it was raised to C20 in 2007 and to C25 in the current 2018 regulation. The differentiation of the reinforcement grade within the structure affected the analysis results at minimal levels. With the increase in the number of low-strength concrete stories, the periods increased, and the structure's total rigidity decreased. The base shear forces obtained for building models with different strengths are very close to the whole structure's value for the lowest strength concrete in the structure. This situation has preserved its validity for the relative displacements. Equal displacements occurred at higher load factors with the increase in concrete strength in different building models. As the concrete strength increases, the structure behaves more rigid and makes fewer displacements. The change in concrete strength within the structure also negatively affected the relative displacement values. All the results obtained once again revealed that concrete strength directly affects the earthquake behaviour of structures.

\section{References}

[1] Yakut A. Preliminary seismic performance assessment procedure for existing RC buildings. $\quad$ Engineering $\quad$ Structures, 2004; 26:1447-1461. https://doi.org/10.1016/j.engstruct.2004.05.011

[2] Ișılk E, Isik M, Bülbül M. Web based evaluation of earthquake damages for reinforced concrete buildings. Earthquakes and Structures 2018; 13:423-432.

[3] Harirchian E, Lahmer T, Buddhiraju S, Mohammad K, Mosavi A. Earthquake safety assessment of buildings through rapid visual screening. Buildings, 2020;10:51. https://doi.org/10.3390/buildings10030051

[4] Harirchian E, Lahmer T, Earthquake hazard safety assessment of buildings via smartphone app: a comparative study. İOP Conference Series: Materials Science and Engineering, 2019;652:012069. https://doi.org/10.1088/1757-899X/652/1/012069

[5] FEMA P-154. Third Edition, Rapid visual screening of buildings for potential seismic hazards: A Handbook, Applied Technological Council (ATC) 2015.

[6] Vallejo CB, others. Rapid visual screening of buildings in the city of Manila, Philippines. 5th Civil Engineering Conference in the Asian Region and Australasian Structural Engineering Conference 2010, The. Engineers Australia, 2010.

[7] Tesfamariam S, Saatcioglu M. Seismic vulnerability assessment of reinforced concrete buildings using hierarchical fuzzy rule base modeling. Earthquake Spectra 2010;26: 235-256. https://doi.org/10.1193/1.3280115

[8] Harirchian E, Lahmer T. Improved rapid visual earthquake hazard safety evaluation of existing buildings using a type-2 fuzzy logic model. Applied Sciences,2020;10:2375. https://doi.org/10.3390/app10072375

[9] Harirchian E, Lahmer T, Kumari V, Jadhav K. Application of support vector machine modeling for the rapid seismic hazard safety evaluation of existing buildings. Energies 2020;13;3340. https://doi.org/10.3390/en13133340

[10] Harirchian E, Lahmer T, Rasulzade S. Earthquake hazard safety assessment of existing buildings using optimized multi-layer perceptron neural network. Energies 2020;13: 2060. https://doi.org/10.3390/en13082060

[11] Tesfamariam S, Liu Z. Earthquake induced damage classification for reinforced concrete buildings. Structural Safety 2010; 32:154-164 https://doi.org/10.1016/i.strusafe.2009.10.002

[12] Sextos A, De Risi R, Pagliaroli A, Foti S, Passeri F, Ausilio E, Cairo R, Capatti MC, Chiabrando F, Chiaradonna A, and others. Local site effects and incremental damage of 
buildings during the 2016 Central Italy earthquake sequence. Earthquake Spectra 2018; 34:1639-1669. https://doi.org/10.1193/100317EQS194M

[13] Borcherdt RD. A theoretical model for site coefficients in building code provisions. Procs. 13thWorld Conference on Earthquake Engineering, 2004.

[14] Büyüksaraç A, Bektas Ö, Yılmaz H, Arısoy MÖ. Preliminary seismic microzonation of Sivas city (Turkey) using microtremor and refraction microtremor (ReMi) measurements. Journal of seismology, 2013;17:425-435. https://doi.org/10.1007/s10950-012-9328-1

[15] Iervolino I, Giorgio M, Cito P. Which earthquakes are expected to exceed the design spectra? Earthquake Spectra, 2019;35:1465-1483. https://doi.org/10.1193/032318EQS0660

[16] Kutanis M, Ulutas H, Işık E. PSHA of Van province for performance assessment using spectrally matched strong ground motion records. Journal of Earth System Science, 2018;127:99. https://doi.org/10.1007/s12040-018-1004-6

[17] Hadzima-Nyarko M, Nikić D, Pavić G. Seismic vulnerability assessment of reinforced concrete frame structure by finite element analysis. Acta Physica Polonica. A, 2019;135; 845-848. https://doi.org/10.12693/APhysPolA.135.845

[18] Hadzima-Nyarko M, Morić, D, Španić M. Spectral functions of RC frames using a new formula for Damage Index. Tehnički vjesnik, 2014;21:163-171.

[19] Işılk MF, Işılk E, Bülbül M.A. (2018). Application of iOS/Android based assessment and monitoring system for building inventory under seismic impact. 2018; 70:1043-1056. https://doi.org/10.14256/JCE.1522.2015

[20] TSDC (2007), Specification for Buildings to be Built in Seismic Zones (2007), Ministry of Public Works and Settlement, Ankara, 2007.

[21] TBEC (2018), Turkish Building Earthquake Code, Prime Ministry, Disaster and Emergency Management Presidency (AFAD), Ankara, 2018

[22] Avşar Ö, Yakut A, Caner A. Analytical fragility curves for ordinary highway bridges in Turkey. Earthquake Spectra. 2011; 27:971-996. https://doi.org/10.1193/1.3651349

[23] Bal IE, Bommer JJ, Stafford PJ, Crowley H, Pinho R. The influence of geographical resolution of urban exposure data in an earthquake loss model for Istanbul. Earthquake Spectra. 2010; 26:619-634. https://doi.org/10.1193/1.3459127

[24] Karaşin İB, Işık E, Demirci A, Aydın MC. The effect of site-specific design spectra for geographical location on reinforced-concrete structure performance. Dicle University journal of Engineering, 2020;13;1319-1330.

[25] Pavić G, Hadzima-Nyarko M, Bulajić B. A contribution to a uhs-based seismic risk assessment in Croatia-A case study for the city of Osijek. Sustainability, 2020;12:1796. https://doi.org/10.3390/su12051796

[26] Ademović N, Hadzima-Nyarko M, Zagora, N. Seismic vulnerability assessment of masonry buildings in Banja Luka and Sarajevo (Bosnia and Herzegovina) using the macroseismic model. Bulletin of Earthquake Engineering, 2020;18:3897-3933. https://doi.org/10.1007/s10518-020-00846-8

[27] Işık E, Büyüksaraç A, Ekinci YL, Aydın MC, Harirchian E. The effect of site-specific design spectrum on earthquake-building parameters: a case study from the Marmara Region (NW Turkey). Applied Sciences, 2020;10:7247. https://doi.org/10.3390/app10207247

[28] AFAD (2020), "Interactive earthquake map web page for the 10.01 .2021 available at https://tdth.afad.gov.tr/"

[29] Ates S, Kahya V, Yurdakul M, Adanur S. Damages on reinforced concrete buildings due to consecutive earthquakes in Van. Soil Dynamics and Earthquake Engineering. 2013;53. https://doi.org/10.1016/i.soildyn.2013.06.006

[30] Inel M, Senel S, Ün H. Experimental evaluation of concrete strength in existing buildings. Magazine of Concrete Research. 2008; 60:279-289. https://doi.org/10.1680/macr.2007.00091 
[31] Binici H. March 12 and June 6, 2005 Bingol-Karliova earthquakes and the damages caused by the material quality and low workmanship in the recent earthquakes. Engineering Failure Analysis. 2007; 14:233 - 238. https://doi.org/10.1016/i.engfailanal.2005.10.020

[32] Su N. Structural evaluations of reinforced concrete buildings damaged by Chi-Chi Earthquake in Taiwan. 2001; 6:119-128. https://doi.org/10.1061/(ASCE)10840680(2001)6:3(119)

[33] Marshall J, Lang AF, Baldridge SM, Popp D. Recipe for disaster: construction methods, materials, and building performance in the January 2010 Haiti Earthquake. Earthquake Spectra.2011;27:323 - 343. https://doi.org/10.1193/1.3637031

[34] Alih SC, Vafaei M. Performance of reinforced concrete buildings and wooden structures during the $2015 \mathrm{Mw}$ 6.0 Sabah earthquake in Malaysia. Engineering Failure Analysis, 2019;102:351-368 https://doi.org/10.1016/j.engfailanal.2019.04.056

[35] Yépez F, Yépez O. Role of construction materials in the collapse of R/C buildings after Mw 7.8 Pedernales - Ecuador earthquake, April 2016. Case Studies in Structural Engineering, 2017;7:24 - 31. https://doi.org/10.1016/j.csse.2016.12.001

[36] Varum H, Dumaru R, Furtado A, Barbosa A, Gautam D, Rodrigues H., Seismic performance of buildings in Nepal after the Gorkha Earthquake; In Impacts and insights of the Gorkha earthquake (pp. 47-63). Elsevier. https://doi.org/10.1016/B978-0-12812808-4.00003-1

[37] Doğangün, A. Performance of reinforced concrete buildings during the May 1, 2003 Bingöl Earthquake in Turkey. Engineering Structures, 2004;26:841-856. https://doi.org/10.1016/j.engstruct.2004.02.005

[38] Antoniou A, Guney Y, Paudyal K. Determinants of corporate capital structure: evidence from European Countries. SSRN Electronic Journal 2002. https://doi.org/10.2139/ssrn.302833

[39] Antoniou S, Pinho R. Development and verification of a displacement-based adaptive pushover procedure. Journal of Earthquake Engineering, 2004;8:643-661. https://doi.org/10.1080/13632460409350504

[40] Ferracuti B, Pinho R, Savoia M, Francia R. Verification of displacement-based adaptive pushover through multi-ground motion incremental dynamic analyses. Engineering Structures, 2009;31:1789-1799. https://doi.org/10.1016/i.engstruct.2009.02.035

[41] Pinho R, Casarotti C, Antoniou S. A comparison of single-run pushover analysis techniques for seismic assessment of bridges. Earthquake Engineering Structural Dynamics, 2007;36:1347 - 1362. https://doi.org/10.1002/eqe.684

[42] Casarotti C, Pinho R. An adaptive capacity spectrum method for assessment of bridges subjected to earthquake action. Bulletin of Earthquake Engineering, 2007;5:377-390. https://doi.org/10.1007/s10518-007-9031-8

[43] Pinho R, Monteiro R, Casarotti C, Delgado R. Assessment of continuous span bridges through nonlinear static procedures. Earthquake Spectra, 2009;25:143-159. https://doi.org/10.1193/1.3050449

[44] Antoniou S, Pinho R. Advantages and limitations of adaptive and non-adaptive forcebased pushover procedures. Journal of Earthquake Engineering, 2004;8; 497-522. https://doi.org/10.1080/13632460409350498

[45] Pinho R, Antoniou S. A displacement-based adaptive pushover algorithm for assessment of vertically irregular frames. Proceedings of the Fourth EuropeanWorkshop on the Seismic Behaviour of Irregular and Complex Structures, 2005.

[46]Aksoylu C, Arslan MH. Çerçeve türü betonarme binaların periyod hesaplarının farklı ampirik bağıntılara göre irdelenmesi. Bitlis Eren Üniversitesi Fen Bilimleri Dergisi, 2019;8:569-581. https://doi.org/10.17798/bitlisfen.476312 
[47] Işık E, Özdemir M. Performance based assessment of steel frame structures by different material models. International Journal of Steel Structures, 2017;17: 10211031. https://doi.org/10.1007/s13296-017-9013-x

[48] Mander JB, Priestley MJ, Park R. Theoretical stress-strain model for confined concrete. Journal of Structural Engineering, 1988;114:1804-1826. https://doi.org/10.1061/(ASCE)0733-9445(1988)114:8(1804)

[49] Menegotto,M. Method of analysis for cyclically loaded RC plane frames including changes in geometry and non-elastic behavior of elements under combined normal force and bending. Proc. of IABSE symposium on resistance and ultimate deformability of structures acted on by well defined repeated loads, 1973.

[50] Antoniou, S.; Pinho, R. Seismostruct-Seismic Analysis program by Seismosoft. Technical manual and User manual 2003.

[51] Seismosoft [2014], "SeismoStruct v7.0 - A computer program for static and dynamic nonlinear analysis of framed structures," available from http://www.seismosoft.com .

[52] Pinto, P.E. The Eurocode 8-Part 3: the new European Code for the seismic assessment of existing structures, 2005. 